Hormone Res. 1987;28:I-IV

\title{
Contents, Vol. 28, 1987
}

\section{No. 1 Pediatric Endocrinology}

Association of Adverse Perinatal Events with an Empty Sella turcica in Children with Growth Hormone Deficiency

Surtees, R.; Adams, J.; Price, D.; Clayton, P.; Shalet, S 5

Comparison of Growth Hormone Response to Growth Hormone-Releasing Factor 1-44 according to the Combined Study of Sleep Secretion with the Responses to Pharmacologic Stimuli

Gamier, P.; Liapi, C; Raynaud, F.; Evain-Brion, D 13

Amniotic Fluid Steroid Levels and Fetal Adrenal Weight in Congenital Adrenal Hyperplasia

Hughes, I.A.; Dyas, J.; Laurence, K.M 20

Androgen Insensitivity in Forty-Nine Patients: Classification Based on Clinical and Androgen Receptor Phenotypes

Hughes, I.A.; Evans, B.A.J 25

The Role of Arginine-Vasopressin in the Regulation of Water Metabolism in Preterm Infants in the First Days of Life

Stegner, H.; Henkel, R.; Commentz, J.C

Transient Ovarian Testosterone and Androstenedione Hypersecretion: A Cause of Virilization or Premature Pubarche in Prepubertal Girls

Muritano, M.; Zachmann, M.; Manella, B.; Briner, J.; Prader, A

Iodine in Contrast Agents and Skin Disinfectants Is the Major Cause for Hypothyroidism in Premature Infants during Intensive Care

ГAllemand, D.; Grüters, A.; Beyer, P.; Weber, B 42

Somatomedin C/Insulin-Like Growth Factor 1: An Intratesticular Differentiative Factor of Leydig Cells?

Morera, A.M.; Chauvin, M.A.; Peretti, E. de; Binoux, M.; Benahmed, M 50

Atrial Natriuretic Peptide in Infants and Children

Rascher, W.; Bald, M.; Kreis, J.; Tulassay, T.; Heinrich, U.; Schärer, K 58

Plasma Atrial Natriuretic Peptide Levels in Children with Cardiac Disease: Correlation with cGMP Levels and Haemodynamic Parameters

Weil, J.; Strom, T.M.; Brangenberg, R.; Sebening, W.; Haufe, M.; Lang, R.E.; Bidlingmaier, F.; Gerzer, R 64

Growth Hormone in Urine: Development of an Ultrasensitive Assay Applicable to Plasma and Urine

Girard, J.; Erb, T.; Pampalone, A.; Eberle, A.N.; Baumann, J.B

Contents

III

No. 2-4 30th International Henri-Pierre Klotz Days of Clinical Endocrinology Paris, May 15-16, 1987 
Recent Advances in the Pharmacological Control of Gonadal Function Caufriez, A.; Forest, M.G.

Preface $\quad 87$

Gonadotropin-Releasing Hormone: Physiological and Therapeutic Aspects, Angonists and Antagonists

Santen, R.J.; Bourguignon, J.-P 88

Studies of the Inhibin Family of Hormones: A Review

Rivier, C; Vale, W.; Rivier, J 104

A Role for the Endogenous Opioid Peptides in the Regulation of Gonadotropin Secretion in the Primate

Ferin, M 119

Contemporary Insights into the Regulation of Luteinizing Hormone Secretion in Man

Veldhuis, J.D 126

Pulsatility of Serum LH in Pathological Conditions

Leyendecker, G.; Wildt, L.; Brensing, K.-A.; Roll, C 139

Treatment of Central Precocious Puberty with an LHRH Agonist (Buserelin): Effect on

Growth and Bone Maturation after Three Years of Treatment

Rappaport, R.; Fontoura, M.; Brauner, R 149

Treatment of Precocious Puberty with a Long-Acting Preparation of E >-TRP6-LHRH

Chaussain, J.-L.; Roger, M.; Couprie, C; Lahlou, N.; Canlorbe, P 155

Use of LHRH Agonists in the Treatment of Anovulation in Women with Polycystic Ovary

Syndrome

Franks, S.; Sagle, M.; Mason, H.D.; Kiddy, D

164

Comparative Effects of Cyproterone Acetate or a Long-Acting LHRH Agonist in Polycystic

Ovarian Disease

Schaison, G.; Couzinet, B 169

Influence of Testosterone Substitution on Sperm Suppression by LHRH Agonists

Bouchard, P.; Garcia, E 175

Antihormone-Steroid Hormonal Activity, Heat-Shock Protein hsp 90 and Receptors

Baulieu, E.-E 181

Nonsteroidal Antiestrogens Are Estrogen-Receptor-Targeted Growth Inhibitors That Can

Act in the Absence of Estrogens

Rochefort, H 196

Antiestrogens, Different Sites of Action than the Estrogen Receptor?

Faye, J.-C; Fargin, A.; Valette, A.; Bayard, F 202

Antiestrogen Action of Progesterone in Breast Tissue

Mauvais-Jarvis, P.; Kuttenn, F.; Gompel, A 212

Antiestrogens as Treatment of Female and Male Infertilities

Buvat, J.; Buvat-Herbaut, M.; Marcolin, G.; Ardaens-Boulier, K 219

Design of Antiandrogens and Their Mechanisms of Action: A Case Study (Anandron)

Raynaud, J.-P.; Fiet, J.; Le Goff, J.-M.; Martin, P.-M.; Moguilewsky, M.; Ojasoo, T. . 230

Antiandrogens and Hirsutism

Biffignandi, P.; Molinatti, G.M 242

New Approaches for the Treatment of Prostatic Hypertrophy and Cancer

Zoppi, S.; Cocconi, M.; Serio, M.; Martini, L., Motta, M 250

IV 


\section{Contents}

Effects of Drug Administration on Gonadotropins, Sex Steroid Hormones and Binding Proteins in Humans

Pugeat, M.; Lejeune, H.; Dechaud, H.; Emptoz-Bonneton, A.; Fleury, M.-C; Charrié, A.; Tourniaire, J.; Forest, M.G 261

Fertility Control with RU 486

Ulmann, A.; Dubois, C; Philibert, D 274

Abstracts 279

Author Index 289

Subject Index 291

S. Karger $\cdot$ Medical and Scientific Publishers

Basel $\cdot$ München $\cdot$ Paris $\cdot$ London $\cdot$ New York $\cdot$ New Delhi $\cdot$ Singapore $\cdot$ Tokyo a Sydney

Drug Dosage

The authors and the publisher have exerted every effort to ensure that drug selection and dosage set forth in this text are in accord with current recommendations and practice at the time of publication. However, in view of ongoing research, changes in government regulations, and the constant flow of information relating to drug therapy and drug reactions, the reader is urged to check the package insert for each drug for any change in indications and dosage and for added warnings and precautions. This is particularly important when the recommended agent is a new and/or infrequently employed drug.

All rights reserved.

No part of this publication may be translated into other languages, reproduced or utilized in any form or by any means, electronic or mechanical, including photocopying, recording, microcopying, or by any information storage and retrieval system, without permission in writing from the publisher or, in the case of photocopying, direct payment of a specified fee to the Copyright Clearance Center (see 'Information for Readers and Subscribers').

(C) Copyright 1987 by

S. Karger AG, P.O. Box, CH-4009 Basel (Switzerland) Printed in Switzerland by Thür AG Offsetdruck, Pratteln 